\title{
Integrated Curriculum Design for an Industrial Engineering Undergraduate Program in Latin America
}

\section{Dr. Angélica Burbano, Universidad Icesi}

Angelica Burbano C.,holds a Ph.D. in Industrial Engineering from the University of Arkansas. She holds a MSOM from Universidad Icesi and a BS in industrial engineering from Pontificia Universidad Javeriana both in Cali, Colombia. She is a Fulbright Scholar 2007 and a fellow AOTS, Japan 2000. Angelica has previous experience (five years) in the food manufacturing industry (experience related to inventory management and production planning and control, also information systems such as ERP). During her studies in the United States she worked a research assistant at the Center for Innovation on Healthcare Logistics CIHL, her work for CIHL focused on assessing the impact of GS1 standards adoption in the healthcare supply chain. Her research interests are related to the modeling of technology adoption and in particular HIT. She also works in the adaptation of existing manufacturing and logistics models and structures to the healthcare supply chain with a specific focus on medical supplies. She is part of the Industrial Engineering Department at Universidad Icesi since 1998. She has over twelve years of teaching experience and has served as Director of the Undergraduate Program in Industrial Engineering (20032007), Director of the graduate program in Industrial Engineering ( August 2012 - August 2014), and she is currently the IE Department Head. 


\title{
Integrated Curriculum Design for an Industrial Engineering Program in Latin America
}

\begin{abstract}
The Industrial Engineering Department at Universidad Icesi led a systematic review of the Industrial Engineering (IE) undergraduate program curriculum. Universidad Icesi at Cali, Colombia is a private institution recognized among the best universities in the country. The curriculum review and design was conceived as part of the IE undergraduate program's continuous improvement process and took into consideration the fundamental principles supporting the institution's educational project or PEI (Proyecto Educativo Institucional), the principles established by CDIO (Conceive-Design-Implement-Operate) approach and the student outcomes defined by ABET.
\end{abstract}

In this paper, the proposed IE integrated curriculum is presented. The curriculum allows for the development of the skills defined in the recent graduating student profile, skills that are mapped to student outcomes (a-k). Assessment results at the course and program levels are presented, as well as the consolidation of the program's continuous improvement process.

\section{Introduction}

This paper presents the Industrial Engineering curriculum review and design as the initial step within the program's continuous improvement process. Once the proposed curriculum is implemented, it is continuously reviewed as student learning is assessed. This paper is based on previous work started at the Universidad Icesi School of Engineering [1] and presents an adaptation of the proposed methodology for the IE undergraduate program. The adaptation presents the grouping of steps according to the PDCA (Plan, Do, Check, Act) cycle and the inclusion of ABET accreditation considerations for program assessment purposes.

\section{Methodology}

The IE Department led a systematic review of the IE undergraduate program curriculum following the process established for all undergraduate engineering programs in the engineering school; this process is described below in Figure 1. Each of the steps was followed and adapted to the program. This adaptation allowed for the revision of the IE curriculum and the consolidation of the program's continuous improvement process which is aligned to the ABET accreditation requirements, as the IE undergraduate program at Universidad Icesi is currently working towards ABET accreditation during the 2016-2017 cycle. 


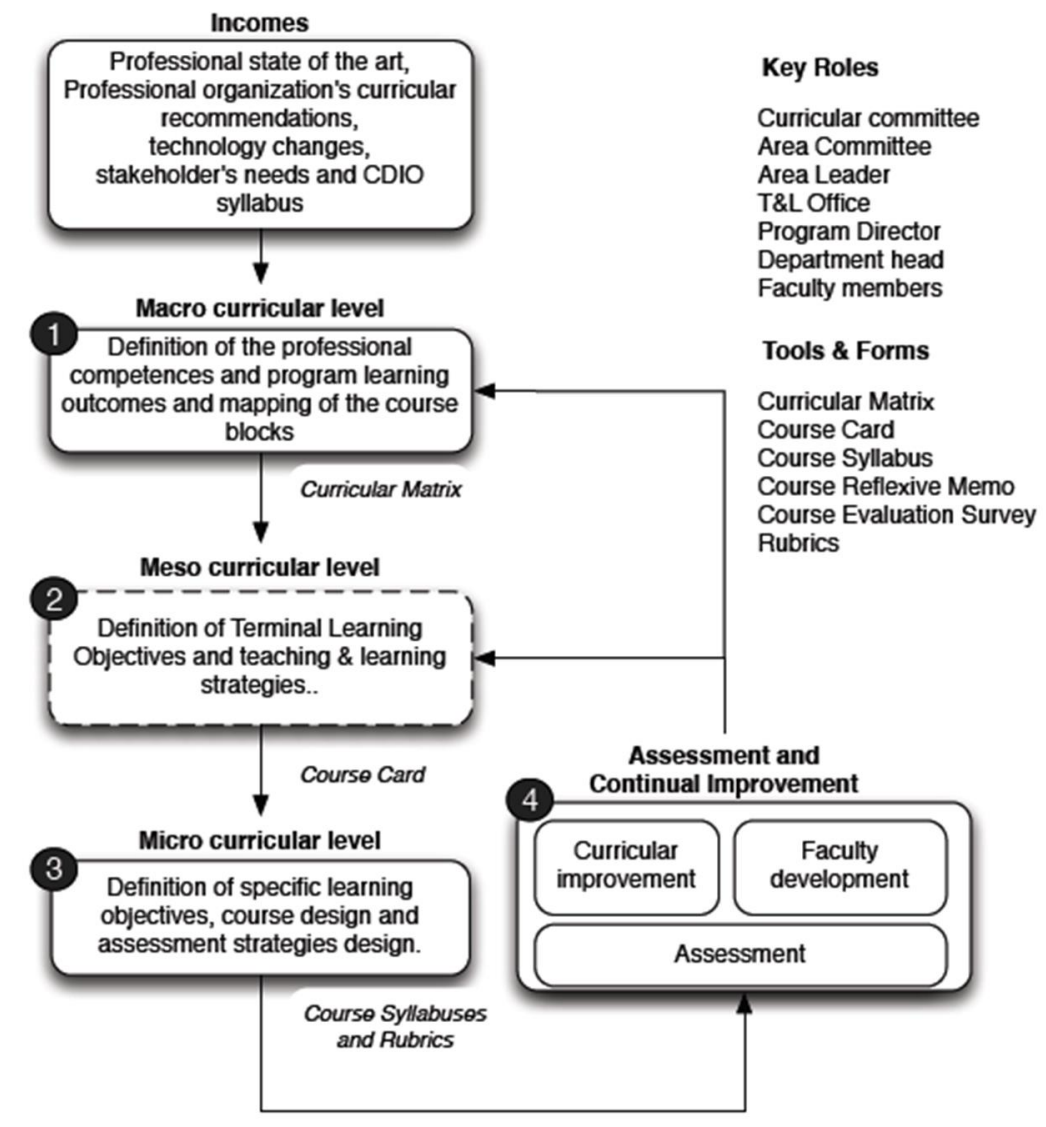

Figure 1. Curricular continuous improvement process [1]

\section{Initial step (Incomes in Figure 1)}

The curriculum review process began in 2013 with the input of constituencies and faculty as well as other sources, such as ABET student outcomes, the PEI [2] and the CDIO framework [3]. A survey was given to employers, alumni, recent graduates, and interns, the goal of which was to identify competencies associated with the IE program at the time of graduation (recent graduating student profile) and additionally within a few years after graduation.

In addition, one benchmark for the IE program's recent graduating student profile was developed. The recent graduating student profile is a brief description of what the program considers the student should be able to do as by the time of graduation. The benchmark analyzed similar profiles from the best IE programs in Colombia, the Americas, and Europe. Lastly, the national standardized test Saber PRO was considered in regards to critical competencies associated with the engineering discipline.

The competencies for the IE recent graduating student profile are:

The Industrial Engineer from the Universidad Icesi will be prepared to meet the challenges of the manufacturing and service sectors relying on their abilities to design and operate systems as well as to analyze and solve engineering problems. These capabilities will allow them to model, 
analyze, and evaluate systems and processes providing alternatives for continuous improvement and the efficient use of resources. Finally, they will have the ability to be active participants in multidisciplinary teams whose goals are the design and development of strategies to ensure the sustainability of the organization. They will also be recognized for their effective communication skills, systems thinking, and leadership.

Based on the recent graduating student profile, the IE faculty developed a preliminary draft of the Program Educational Objectives (PEOs). The PEOs state what graduates should be able to do within a few years of graduation. Graduates of the IE undergraduate program will:

PEO1 Advance as a leading Industrial Engineering professional within manufacturing or service organizations.

PEO2 Use their knowledge and skills to lead projects for the optimal use of resources and continuous improvement.

PEO3 Use their teamwork and system thinking skills as well as their ability to adapt to change in order to stay current in their field.

The PEOs and the recent graduating student profile were reviewed by the IE Curricular Committee and then amended and approved by the Engineering School Council.

The student outcomes for the Industrial Engineering (IE) program cover the knowledge, skills, and abilities required for Icesi's students to achieve the program's PEOs within a few years after graduation. These outcomes are based on ABET definitions for student outcomes. The student outcomes for the IE program are:

a) an ability to apply knowledge of mathematics, science, and engineering

b) an ability to design and conduct experiments, as well as to analyze and interpret data

c) an ability to design a system, component, or processes to meet desired needs within realistic constraints such as economic, environmental, social, political, ethical, health and safety, manufacturability and sustainability

d) an ability to function on multidisciplinary teams

e) an ability to identify, formulate, and solve engineering problems

f) an understanding of professional and ethical responsibility

g) an ability to communicate effectively orally and written, both in Spanish and English

h) the broad education necessary to understand the impact of engineering solutions in global, economic, environmental, and societal contexts

i) a recognition of the need for, and an ability to engage in life-long learning

j) a knowledge of contemporary issues

k) an ability to use the techniques, skills, and modern engineering tools necessary for engineering practice.

The student outcomes provide a solid basis and support for Icesi graduates to achieve the Program Educational Objectives. The associations between the PEOs and the given student outcomes are explained in the following paragraphs. 
PEO1 - Advance as a leading industrial engineering professional in manufacturing or service organizations. The curriculum prepares graduates to design systems taking into consideration requirements and restrictions associated with the environmental, social, and economic issues in contemporary context. The awareness of the ethical implications of their engineering decisions as well as the adherence to the code of ethics, will allow the students to advance as leaders in manufacturing or service organizations. Relevant outcomes are: $\mathrm{c}, \mathrm{f}, \mathrm{h}, \mathrm{j}$

PEO2 - Use their knowledge and skills to lead projects for the optimal use of resources and the continuous improvement. The curriculum prepares graduates to solve problems and to use modern engineering techniques for industrial engineering practice. Project management skills will contribute to the execution of improvement plans that will facilitate the continuous improvement of organizations. Relevant outcomes are: a, b, e, g, k

PEO3 - Use their teamwork and systems thinking skills as well as their ability to adapt to change in order to keep current in their field. The curriculum develops life-long learning skills that will allow graduates to adapt and stay current in their field considering the rapid technological changes that they will have to face in manufacturing or service organizations. Teamwork and systems thinking abilities will contribute to the search for innovative mechanisms to adapt to this constantly changing environment. Therefore, relevant outcomes are: $\mathrm{d}, \mathrm{g}, \mathrm{h}, \mathrm{i}, \mathrm{j}$

Once the PEOs were defined and aligned with the student outcomes, an examination of the current IE undergraduate curriculum was conducted.

\section{Macro curricular level}

The IE undergraduate curriculum was reviewed in order to align PEOs and student outcomes with the current plan of study. The review was conducted over two semesters (2013-2 and 20141) and it was approved in the second semester of 2014. The new plan of study (shown in Table 1) was first implemented in 2015-1. The main academic terms at Universidad Icesi are based on semesters. The academic year consists of two semesters of 18 weeks each (16 weeks dedicated to instruction, plus two weeks devoted to final examinations). The first semester starts at the beginning of January and ends in May, and the second starts at the end of July and ends in November. Some courses are offered in a six-week summer term that takes place between June and July.

Besides the courses presented in Table 1, Universidad Icesi requires that all students pass eight levels of English. Once students are enrolled in the first semester of their program, the university administers an English proficiency examination. Students who demonstrate the required proficiency are free to take courses in the other languages offered by the university, the cost of which are included in the tuition. Universidad Icesi also requires that students demonstrate proficiency in the usage of productivity software for their academic work (i.e., MS Power Point, MS Word and MS Excel). As with the English requirement, a proficiency examination is given during the first week of the first semester. Students who do not demonstrate the required proficiency must enroll in courses offered by the University at no extra cost. At the end of each English level students must demonstrate proficiency in order to move on to the next. 


\section{Curriculum Alignment with Program Educational Objectives}

All PEOs of the IE program require a strong preparation in the concepts, skills, and abilities of an Industrial Engineer as a well-rounded professional. This preparation is achieved through courses in math \& basic sciences, engineering topics, and general education subject areas. Furthermore, the Professional Internship provides the environment for students to apply in real life the knowledge and skills that will allow them to achieve the PEOs of the program within a few years of graduation.

PEO 1. Advance as a leading Industrial Engineering professional within manufacturing or service organizations. This PEO requires students to be prepared to appropriately manage manufacturing or service organizations. This preparation is achieved through a series of courses that develop the required skills to design processes that serves the organization needs. Courses such as 01302 - Organizations, 01303 - Leadership, 05162 - Operations Planning and Control, and 05166 - Facilities Layout provide the required background that facilitates the students' advancement as capable industrial engineering professionals.

There are additional courses, including 05221 - Life Cycle engineering and 04121 - Engineering Economics that present the context in which organizations operate and where students must take into consideration various restrictions. Because ethics is a major concern in the IE Program, in the first semester students are introduced to fundamental topics in ethics such as plagiarism, through 05250 - Introduction to Engineering, Graduation Project I, Graduation Project II as well as an elective in ethics which they take at the end of their program. Before the students begin their internships, the Code of Ethics is reviewed (they develop a case study during an internship follow up session) and the Code is given to them in printed form in a special ceremony. Ethics is essential in order to advance as leading IE professionals.

PEO 2. Use their knowledge and skills to lead projects for the optimal use of resources and continuous improvement. This PEO requires students to be proficient not only in the disciplinary topics of the program but also on the foundational ones which are associated with math, statistics and basic sciences. Students should be able to apply math and science to the solving of engineering problems; courses such as 05231- Lean Manufacturing, 05167 - Quality in Operations, 05226 - Systems Thinking, and 05180 - Process and Procedures provide the required background. For the optimal use of resources, modeling skills are acquired through a series of courses in that area: 09748 - Algorithmic thinking, 05173 - Operations Research, 05191 Stochastic Processes and 05294 - Discrete Simulation.

Students develop project management skills during the courses 05225 - Engineering Project Management, 05174 - Graduation Project I and 05175 - Graduation Project II. These skills will allow students to lead projects aimed at optimizing the use of resources and for continuous improvement. Students should also be able to adequately communicate the results of their work.

PEO 3. Use their teamwork and system thinking skills, as well as their ability to adapt to change in order to keep current in their field. Teamwork and systems thinking skills are developed throughout the curriculum and play an important role in all curricular related activities such as class projects and field visits. Students learn about change during class projects, where it may 
become necessary to adjust the solution and approach based on new information, changing assumptions and other variables. This is part of developing an engineering mindset. A constantly changing environment poses a challenge for IE professionals, who will be required to stay current in their field, and in order to manage such change it will be fundamental to develop lifelong learning skills. Life-long learning is not explicitly taught in the curriculum but is embedded in all courses of the curriculum by motivating students to apply the active learning method in their learning process. Active learning and life-long learning are essential components of the institutional educational project at Universidad Icesi.

\section{Curriculum alignment with Student Outcomes}

The courses summarized in Table 2 correspond to the courses associated with Math \& Basic Sciences and to Engineering Topics. This table shows the manner in which the engineering courses of the curriculum support the attainment of student outcomes. Each cell indicates the level of support provided by the course to the corresponding outcome. Levels of support may correspond to ' $\mathrm{I}$ ', ' $\mathrm{T}$ ' and 'A', which indicates that the course introduces, teaches or allows students to apply topics important for the attainment of the outcome. A cell highlighted in gray indicates that the course constitutes a source of direct assessment for a given student outcome.

To graduate, students must complete 179 credit hours. Courses in the curriculum of the IE Program are classified into three groups: Math \& Basic Sciences, Engineering Topics, and general education. Courses in math and basic sciences (48 credit hours), together with general education (54 credit hours), comprise what Universidad Icesi refers to as the central curriculum. The 77 credits devoted to Engineering Topics include a graduation project that lasts for two semesters and a mandatory internship semester (co-op experience). Engineering Topics include three specific IE areas of knowledge (also known as course blocks) Modeling and Simulation, Resource Management and Sustainability, and Design and Management of Manufacturing and Service Processes.

The graduation project is supervised by a faculty member of the IE Department, and may be focused on either solving an engineering problem or contributing to a research project. Very frequently, engineering problems correspond to real life needs of Colombian companies. The company involved supports the project by assigning an engineer who acts as a co-supervisor of the project. Graduation projects are developed through the courses 05174 - Graduation Project I and 05175 - Graduation Project II, which are capstone projects focused on the development of professional skills such as project management, problem solving, and communication. The co-op experience is a professional internship that must last no less than six months.

For the courses identified as assessment sources (See Table 2 - highlighted courses) of student outcomes, a review of the main competences to develop in the course, using the CDIO version 2.0 syllabus, was performed. The main CDIO skills were assigned to the course block level and course level via the curricular map.

Faculty members worked on the alignment of the course objectives, learning strategies and assessments in order to ensure the development of specific skills throughout the course blocks. Adjustments have been made to course programs belonging to the same course block in order to 
guarantee the continuity in the development of specific skills. In the past, course programs were disconnected, and students could perceive that lack of connection causing difficulties in competencies attainment.

\section{Meso and micro curricular level}

For the assessment courses identified at the macro curricular level, the development of the assessment plan, course card, course syllabus and rubrics was undertaken. The assessment plan is a new element in the process. The assessment was guided by the student outcome leaders, who are faculty members in charge of a particular student outcome. Detailed assessment plans for each student outcome (a-k) were developed. The listed forms (see Figure 1) were defined and implemented on a given course; in this paper just assessment courses are referenced. Once the course is offered, the course evaluation survey and the course reflexive memo are outputs that feed the assessment and evaluation process.

As an example of an assessment plan, the assessment plan for student outcome $\mathrm{g}$ is provided in Appendix 1.

For the IE program there are assessment results for outcomes e, $g$ and h (2015 1). During 20152 data on student outcomes $\mathrm{a}, \mathrm{b}, \mathrm{d}, \mathrm{f}$ and $\mathrm{k}$ was collected and is currently being evaluated. By the first semester of 2016 the program plans to have assessment results for outcomes c, i, and j. Data collection and evaluation frequency will be adjusted after this first assessment cycle in order to have a sustainable process.

\section{Assessment and continuous improvement process}

There is a leader per student outcome in charge of developing the assessment plan. The assessment plan includes performance indicators associated with each outcome and methods for gathering and assessing student work (e.g. student products and rubrics for scoring student products). The student outcome leader develops an initial evaluation report and develops an improvement action plan. Any member of the Assessment Committee can act as an outcome leader. The performance indicators (PIs), assessment plan, rubrics, and process for collecting information are reviewed and approved by the Assessment Committee.

The Assessment Committee is composed of the Department Head, the Program Director, and faculty members that represent each of the disciplinary areas of the program, and the Director of the Continuous Improvement and Accreditation Office (MECA for its acronym in Spanish: Oficina de Mejoramiento Continuo y Acreditación)

In addition to the assessment results obtained, the outcome leader uses input from three different sources for the analysis: the course card, the course syllabus, and the reflective memo. The course card contains the key competencies to be developed, the general objectives and the general learning strategies. The course syllabus contains the detailed course learning goals and learning units. The reflective memo contains the faculty self-assessment report about learning strategies and explains how learning strategies support the achievement of competencies and learning goals. The student outcome leader and faculty involved in the courses associated with 
the outcome discuss the assessment findings and identify improvement opportunities and a preliminary action plan. These findings are presented to the Assessment Committee, which generates a final Student Outcome Evaluation Report, which includes the improvement plan to be implemented the next time the courses are taught.

These improvement plans are monitored by the Curricular Committee at a micro-curricular level (courses) or the Assessment Committee at a macro level (program) as appropriate. Therefore, by the time of defining an improvement plan, some activities may be written in general terms while the specific strategies are defined among the relevant parties.

Finally, after implementing action plans, the assessment process cycle is repeated for a new cycle that begins every three years with a review of PIs for all student outcomes. The MECA office is in charge of collecting and processing the results, as well as ensuring that all information is upto-date and available.

\section{Results and discussion}

\section{Program assessment results}

Based on the proposed design (IE curriculum) the assessment plans for the year 2015 were developed, those plans include student outcomes e, g, h, a, b, d, e and k; data was collected and evaluated. The role of the student outcome leader is fundamental in the assessment process, which is guided by the Assessment and Evaluation Committee.

An example of a final evaluation report for a given outcome is presented in Appendix 1, it shows the final evaluation report for student outcome $\mathrm{g}$. This report includes the assessment plan, the results and a summary table with the improvement actions.

Since this is the first assessment cycle conducted by the IE program, a baseline has yet to be established to define specific targets for each outcome. Instead, a general target for all outcomes was expected. Thus, it was expected that at least $70 \%$ of the assessed students would be at the proficient or outstanding levels. For each outcome, the baseline results will be reviewed as part of the evaluation and continuous improvement process in order to establish more appropriate expected levels of performance going forward.

Based on the recent assessment process (2015), the IE program has identified improvement opportunities. Some of those improvements include, among others:

The adoption of the IEEE code of ethics: The need for providing students with ethical values applicable to their own discipline. The IEEE code of ethics is now introduced in the Introduction to Engineering course, and revisited before students begin their professional internship in a formal ceremony: students receive the code and commit to following it throughout their professional lives.

Strengthening the formative process: The need for incorporating the use of system thinking tools across the curriculum. These tools will contribute to improve problem solving skills, and to 
provide a better understanding of the impact of engineering solutions in society. This is being implemented by professors from the beginning of the course Processes and Procedures.

Similarly, courses across the curriculum are incorporating learning strategies oriented toward strengthening written and oral communication. We believe that practice along the curriculum is the best mechanism for developing these communication skills. Recent developments in courses linked to the development of communication skills have led to the presentation of best practices as a reference for other institutions [4].

Development of a capstone course project: The need for incorporating a capstone course (i.e., major design experience) that exposes students to a multidisciplinary environment and hands-on experiences. Currently, the IE program has major course projects that are not integrated as a capstone course or major design experience. This improvement requires human, economic, and academic resources that are not in place yet.

\section{IE Program Continuous Improvement Process}

Before the proposed review and curriculum design, the program improvement process was running but not aligned to ABET requirements and did not consider feedback from course and program assessment results; it was not a formal process.

The process presented in Figure 1 can be viewed as a PDCA (Plan - Do - Check - Act) cycle for continuous improvement that integrates the following phases: the design phase, which encompasses Macro, Meso and Micro curricular level design (Plan); Course deployment (Do); Assessment and evaluation ( Check ) and implementation of improvement plans (Act).

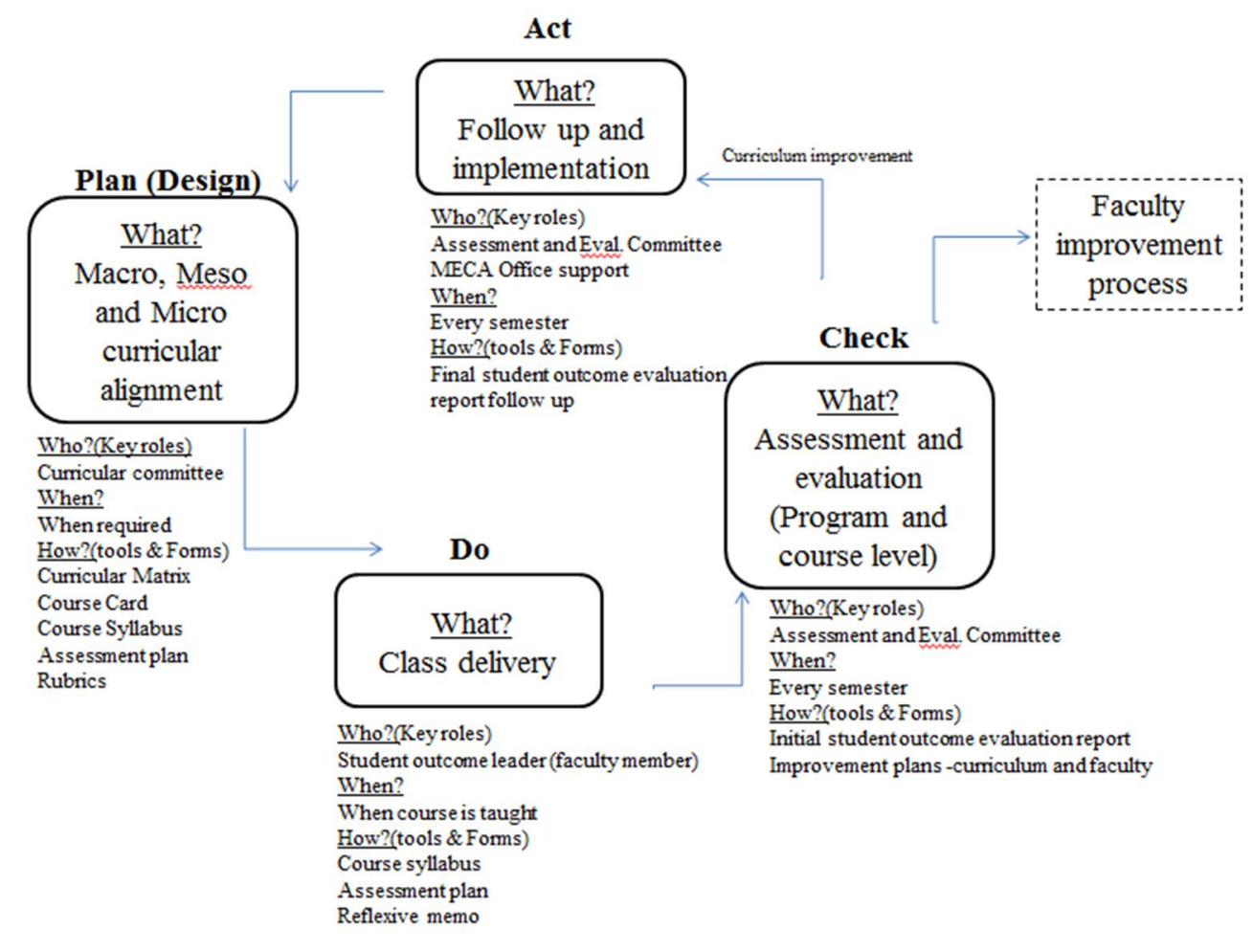


Figure 2. IE program continuous improvement process (PDCA cycle)

Improvement to the Industrial Engineering (IE) undergraduate program and its curriculum is a continuous process based on input from different sources. The Curriculum Committee is in charge of implementing curriculum changes at the macro, meso and micro level and conducting periodic reviews of course offerings. The Assessment Committee is in charge of the overall program assessment and evaluation at the macro level.

The process for assessing and evaluating the extent to which the student outcomes are being attained and how these results are used for continuous improvement of the Industrial Engineering (IE) undergraduate program, as well as the faculty that supports the assessment and evaluation process are the ultimate goal of the process.

\section{Conclusions}

Curriculum review and alignment are the basis for a solid start in program assessment.

The student outcome leader role, usually fulfilled by a full time faculty member, is an important one in the assessment and evaluation process. The Student Outcome leader executes the assessment plan, collects the data, analyzes it and develops the initial evaluation report for a given student outcome.

The assessment and evaluation process generates improvement plans that feed the program in the short, medium and long term. Proper follow-up is required in order to assure the completion of the proposed plans.

For the IE Department, the consolidation of the continuous improvement process at the program level for curriculum improvement and at the faculty level for faculty development was something revealing. The interaction between these two loops is critical in ensuring a high quality engineering program.

Faculty training in proper teaching methods is essential. No improvements can be achieved if we as faculty do not change the way we teach. The faculty improvement process is also to be developed as a PDCA cycle.

Future work includes data gathering for 2016 and the preparation of the self-study report towards ABET accreditation.

\section{Acknowledgments}

The author wishes to acknowledge the support of the IE ABET accreditation team and the MECA office at Universidad Icesi. 


\section{Bibliography}

[1] N. Villegas, S. Cespedes, G. Ulloa y M. P. Ayala, «An approach to implement CDIO,» de Proceedings of the 10th International CDIO Conference, Barcelona, 2014.

[2] H. Gonzalez, El aprendizaje activo y la formación universitaria, Cali: Universidad Icesi, 2011.

[3] E. Crawley, S. Malmqvist, D. Brodeur y K. Edströn, Rethinking Engineering Education, Springer, 2014.

[4] A. Burbano, H. Cancelado y A. Lopez, «La escritura como aprendizaje disciplinar,» de Memorias Conferencia ACOFI, Cartagena, 2014. 


\section{Programa de Ingeniería Industrial

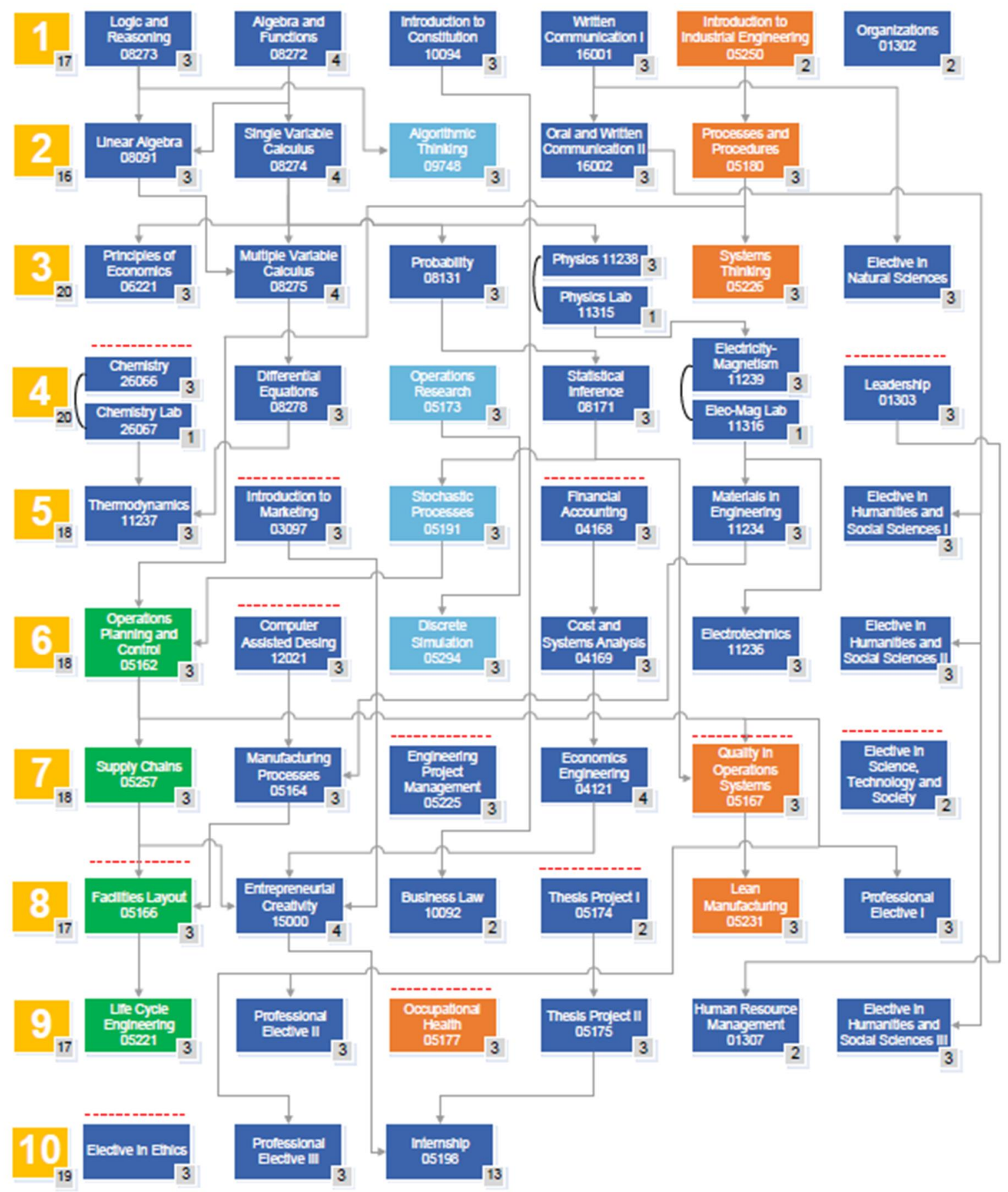

Table 1 - IE Program new curriculum 


\begin{tabular}{|c|c|c|c|c|c|c|c|c|c|c|c|c|}
\hline Course & $\begin{array}{l}\text { IE Program } \\
\text { curriculum }\end{array}$ & a. & b. & c. & d. & e. & f. & g. & h. & i. & j. & k. \\
\hline Code & Course name & \multicolumn{11}{|c|}{ Math \& Basic Science } \\
\hline 08272 & Algebra and Functions & $(\mathrm{T})$ & & & & & & & & & & \\
\hline 08273 & $\begin{array}{l}\text { Formal and Informal } \\
\text { Logic }\end{array}$ & $(\mathrm{T})$ & & & & & & $(\mathrm{I}, \mathrm{T})$ & & & & \\
\hline 08091 & Linear Algebra & $(\mathrm{T})$ & & & & & & & & & & \\
\hline 08274 & One Variable Calculus & $(\mathrm{T})$ & & & & & & & & & & \\
\hline 08275 & $\begin{array}{c}\text { Multiple Variable } \\
\text { Calculus }\end{array}$ & $(\mathrm{T})$ & & & & & & & & & & \\
\hline 08131 & Probability & $(\mathrm{T})$ & $(\mathrm{T})$ & & & & & & & & & \\
\hline 11238 & Physics and Lab & & (T) & & & & & & & & & \\
\hline 26066 & Chemistry & & $(\mathrm{T})$ & & & & & & & & & \\
\hline 08278 & Differential Equations & $(\mathrm{T})$ & & & & & & & & & & \\
\hline 11239 & $\begin{array}{l}\text { Electricity-magnetism } \\
\text { and Lab }\end{array}$ & $(\mathrm{T})$ & & & & & & & & & & \\
\hline 08171 & Statistical Inference & & $(\mathrm{T})$ & & & & & & & & & $(\mathrm{T})$ \\
\hline 11237 & Thermodynamics & (A) & & & & & & & & & & \\
\hline 11234 & Materials in Engineering & $(\mathrm{T})$ & & & & & & & & & & \\
\hline
\end{tabular}




\begin{tabular}{|c|c|c|c|c|c|c|c|c|c|c|c|c|}
\hline Course & $\begin{array}{l}\text { IE Program } \\
\text { curriculum }\end{array}$ & a. & b. & c. & d. & e. & f. & g. & h. & i. & j. & k. \\
\hline 11236 & Electrotechnics & $(\mathrm{T})$ & & & & & & & & & & \\
\hline Code & Course name & \multicolumn{11}{|c|}{ Engineering topics } \\
\hline 05250 & $\begin{array}{l}\text { Introduction to Industrial } \\
\text { Engineering }\end{array}$ & & & & (I) & & (I) & & (I) & & (I) & \\
\hline 09748 & Algorithmic Thinking & & & & & $(\mathrm{I}, \mathrm{T})$ & & & & & & $(\mathrm{T})$ \\
\hline 05180 & $\begin{array}{l}\text { Processes and } \\
\text { Procedures }\end{array}$ & & (I) & $(\mathrm{I}, \mathrm{T})$ & & $(\mathrm{I}, \mathrm{T})$ & & & & & & \\
\hline 05226 & Systems Thinking & & & & $(\mathrm{T})$ & $(\mathrm{I}, \mathrm{T})$ & & $(\mathrm{T})$ & & & & $(\mathrm{T})$ \\
\hline 05173 & Operations Research & $(\mathrm{T})$ & & & & $(\mathrm{T})$ & & & & & & (T) \\
\hline 05191 & Stochastic Processes & $(\mathrm{T})$ & & & & $(\mathrm{T})$ & & & & & & $(\mathrm{T}, \mathrm{A})$ \\
\hline 05162 & $\begin{array}{c}\text { Operations Planning and } \\
\text { Control }\end{array}$ & (A) & & $(\mathrm{T})$ & & & & & $(\mathrm{T})$ & & & $(\mathrm{T})$ \\
\hline 12021 & $\begin{array}{c}\text { Computer Assisted } \\
\text { Design }\end{array}$ & & & & & & & & & & & \\
\hline 05294 & Discrete Simulation & $(\mathrm{A})$ & & & & (A) & & & & & & $(\mathrm{T}, \mathrm{A})$ \\
\hline 05257 & Supply Chains & (A) & & $(\mathrm{T}, \mathrm{A})$ & & & & & $(\mathrm{T})$ & & & $(\mathrm{T}, \mathrm{A})$ \\
\hline 05164 & Manufacturing Processes & & & & & & & & & & & $(\mathrm{T})$ \\
\hline 05225 & Eng.Project Management & & & & (A) & & & & & & $(\mathrm{T})$ & \\
\hline
\end{tabular}




\begin{tabular}{|c|c|c|c|c|c|c|c|c|c|c|c|c|}
\hline Course & $\begin{array}{l}\text { IE Program } \\
\text { curriculum }\end{array}$ & a. & b. & c. & d. & e. & f. & g. & h. & i. & j. & k. \\
\hline 05167 & $\begin{array}{c}\text { Quality in Operations } \\
\text { Systems }\end{array}$ & $(\mathrm{T})$ & (A) & & & (A) & & $(\mathrm{T}, \mathrm{A})$ & & & & $(\mathrm{T})$ \\
\hline 05166 & Facilities Layout & (A) & & $(\mathrm{T}, \mathrm{A})$ & (A) & & & & $(\mathrm{T})$ & & & $(\mathrm{T})$ \\
\hline 05174 & Graduation Project I & & & & (A) & & $(\mathrm{T})$ & (A) & & (A) & & \\
\hline 05231 & Lean Manufacturing & (A) & & & & (A) & & & & & & (A) \\
\hline 05221 & Life Cycle Engineering & & & (A) & & & & & (A) & & & $(\mathrm{T})$ \\
\hline 05175 & Graduation Project II & & & & (A) & & (A) & (A) & & & (A) & (A) \\
\hline 05177 & Occupational Health & & & $(\mathrm{T}, \mathrm{A})$ & & (A) & & & & & & \\
\hline 05198 & Professional Internship & & & & (A & (A) & (A) & (A) & & (A) & & \\
\hline
\end{tabular}

Table 2 - Student Outcomes $(\mathrm{a}-\mathrm{k})$ vs. IE curriculum

(Introduce - I), (Teach - T), (Apply - A) 


\section{Appendix 1 - Assessment Evaluation Report}

Outcome G An ability to communicate effectively (orally and written), both in Spanish and English.

Outcome Leader: Angélica Burbano Collazos.

\begin{tabular}{|c|c|c|c|c|c|c|}
\hline Performance Indicator & Curricular Mapping & $\begin{array}{c}\text { Source of } \\
\text { Assessment }\end{array}$ & $\begin{array}{l}\text { Assessment } \\
\operatorname{Method}(\mathbf{s})\end{array}$ & $\begin{array}{l}\text { Date of } \\
\text { Data } \\
\text { Collection } \\
\text { (Freq.) } \\
\end{array}$ & $\begin{array}{c}\text { Person in } \\
\text { charge of } \\
\text { data } \\
\text { collection } \\
\end{array}$ & $\begin{array}{c}\text { Date of } \\
\text { Evaluation } \\
\text { (Freq.) }\end{array}$ \\
\hline $\begin{array}{l}\text { G-PI1 (Written } \\
\text { Communication) } \\
\text { Produce documents that } \\
\text { show evidence of } \\
\text { communication strategies and } \\
\text { structure. Documents must } \\
\text { feature correct grammar and } \\
\text { style. }\end{array}$ & $\begin{array}{l}\text { - Written } \\
\text { Communication I (I) } \\
\text { - Systems Thinking (T) } \\
\text {-Quality in Operations } \\
\text { Systems (A) } \\
\text { - Graduation Project I } \\
\text { (A) } \\
\text { - Professional Internship } \\
\text { (A) }\end{array}$ & $\begin{array}{l}\text { Graduation } \\
\text { Project I (A) }\end{array}$ & $\begin{array}{l}\text { Rubric } \\
\text { applied at } \\
\text { the end of } \\
\text { the course - } \\
\text { Direct } \\
\text { assessment }\end{array}$ & \multirow{2}{*}{$\begin{array}{l}\text { 2015-1 } \\
\text { (Yearly) }\end{array}$} & $\begin{array}{l}\text { Professor } \\
\text { in charge } \\
\text { of the } \\
\text { course } \\
\text { Graduation } \\
\text { Project I }\end{array}$ & \multirow{2}{*}{$\begin{array}{c}\text { 2015-1 } \\
\text { Biannual }\end{array}$} \\
\hline $\begin{array}{l}\text { G-PI2 (Oral Presentation). } \\
\text { Produce oral presentations } \\
\text { that evidence communication } \\
\text { strategies. Presentations must } \\
\text { feature appropriate language, } \\
\text { style, flow and nonverbal } \\
\text { language (gestures, eye } \\
\text { contact, poise, voice level and } \\
\text { tone). }\end{array}$ & $\begin{array}{l}\text {-Oral and Written } \\
\text { Communication II (I) } \\
\text {-Project management (T) } \\
\text { - Graduation Project I (T) } \\
\text { - Graduation Project II } \\
\text { (A) }\end{array}$ & $\begin{array}{l}\text { Graduation } \\
\text { Project II } \\
\text { (A) }\end{array}$ & $\begin{array}{l}\text { Rubric } \\
\text { applied at the } \\
\text { end of the } \\
\text { course - } \\
\text { Direct } \\
\text { assessment }\end{array}$ & & $\begin{array}{l}\text { Professor } \\
\text { in charge } \\
\text { of the } \\
\text { course } \\
\text { Graduation } \\
\text { Project II }\end{array}$ & \\
\hline
\end{tabular}




\begin{tabular}{|c|c|c|c|c|c|c|}
\hline Performance Indicator & Curricular Mapping & $\begin{array}{c}\text { Source of } \\
\text { Assessment }\end{array}$ & $\begin{array}{l}\text { Assessment } \\
\operatorname{Method}(s)\end{array}$ & $\begin{array}{l}\text { Date of } \\
\text { Data } \\
\text { Collection } \\
\text { (Freq.) }\end{array}$ & $\begin{array}{l}\text { Person in } \\
\text { charge of } \\
\text { data } \\
\text { collection }\end{array}$ & $\begin{array}{l}\text { Date of } \\
\text { Evaluation } \\
\text { (Freq.) }\end{array}$ \\
\hline \multirow{2}{*}{$\begin{array}{l}\text { G-PI3 (Argumentation). } \\
\text { Build and defend arguments } \\
\text { that demonstrate coherence } \\
\text { between conclusions and their } \\
\text { supporting premises. }\end{array}$} & \multirow{2}{*}{$\begin{array}{l}\text { - Logic and } \\
\text { Argumentation (I) } \\
\text { - Engineering Project } \\
\text { management (T) } \\
\text { - Graduation Project II } \\
\text { (A) } \\
\text { - Professional Internship } \\
\text { (A) }\end{array}$} & & $\begin{array}{l}\text { Rubric } \\
\text { applied at the } \\
\text { end of the } \\
\text { course - } \\
\text { Direct } \\
\text { assessment }\end{array}$ & & $\begin{array}{l}\text { Professor } \\
\text { in charge } \\
\text { of the } \\
\text { course } \\
\text { Graduation } \\
\text { Project II }\end{array}$ & \\
\hline & & $\begin{array}{l}\text { Professional } \\
\text { Internship - } \\
\text { IND }\end{array}$ & $\begin{array}{l}\text { Employer } \\
\text { survey - } \\
\text { Indirect } \\
\text { Method }\end{array}$ & & $\begin{array}{l}\text { MECA } \\
\text { Office }\end{array}$ & \\
\hline $\begin{array}{l}\boldsymbol{G - P I 4} \text { Demonstrate an } \\
\text { English proficiency level of at } \\
\text { least B2 by the time of } \\
\text { graduation }\end{array}$ & - English levels 1 to 8 & $\begin{array}{l}\text { National } \\
\text { Standard test } \\
\text { Saber PRO }\end{array}$ & $\begin{array}{l}\text { SABER PRO } \\
\text { (Colombian } \\
\text { state test) }\end{array}$ & $\begin{array}{l}2014 \\
\text { (Yearly) }\end{array}$ & $\begin{array}{l}\text { MECA } \\
\text { Office }\end{array}$ & \\
\hline \multicolumn{3}{|c|}{ Complementary assessment sources } & $\begin{array}{l}\text { Student } \\
\text { outcome } \\
\text { survey }\end{array}$ & $\begin{array}{l}2015-1 \\
\text { (semiannuall } \\
y \text { y) }\end{array}$ & $\begin{array}{l}\text { MECA } \\
\text { Office }\end{array}$ & $\begin{array}{c}\text { 2015-1 } \\
\text { Biannual }\end{array}$ \\
\hline
\end{tabular}


G-PI1 Written Communications - Graduation Project | 2015-1

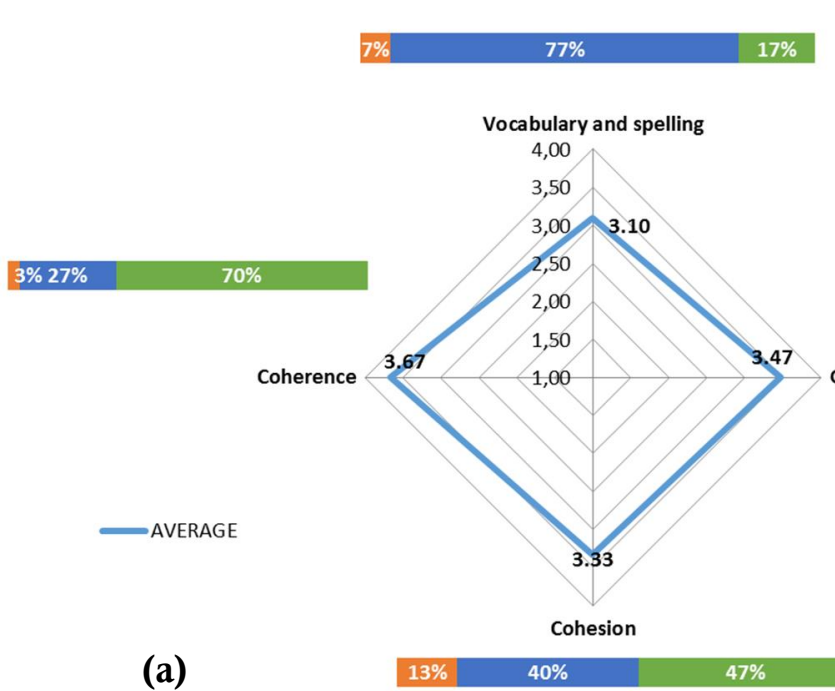

Figure 1 Assessment results for Outcome G

(a) Direct assessment results for G-PI1

(b) Direct assessment results for G-PI2

(c) Direct assessment results for G-PI3

(d) Indirect assessment results for G-PI3
G-PI2 Oral presentation - Graduation Project II 2015-1

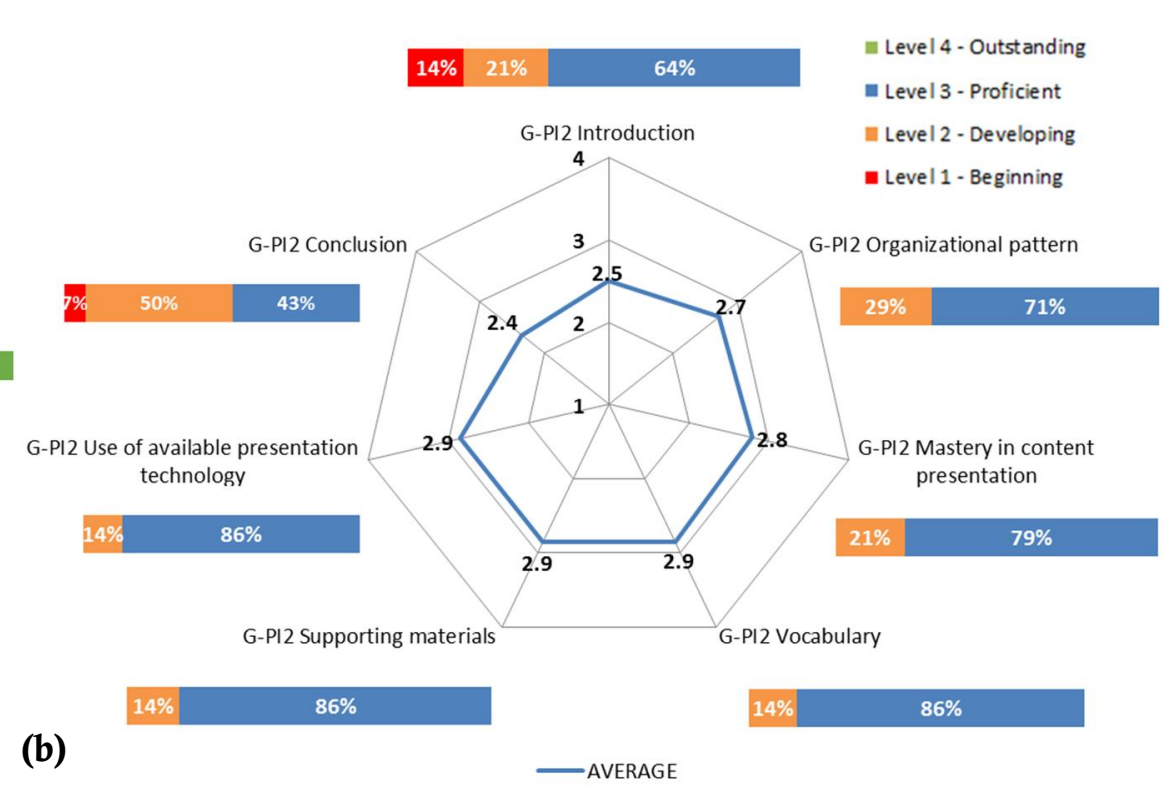

(c)

G-PI3 Argumentation - Graduation Project II 2015-1

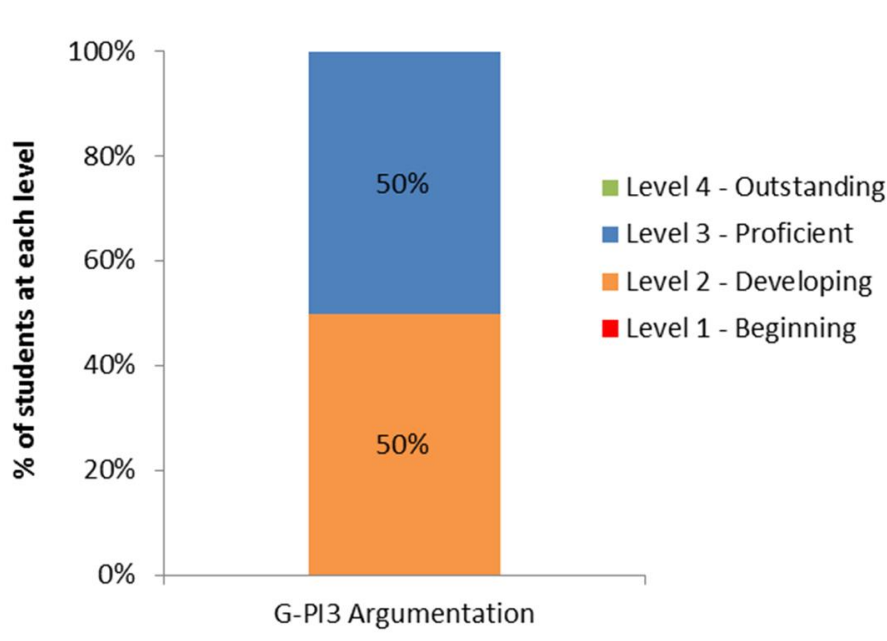

(d)

G-PI-3 Argumentation - Employers Survey 2014-2

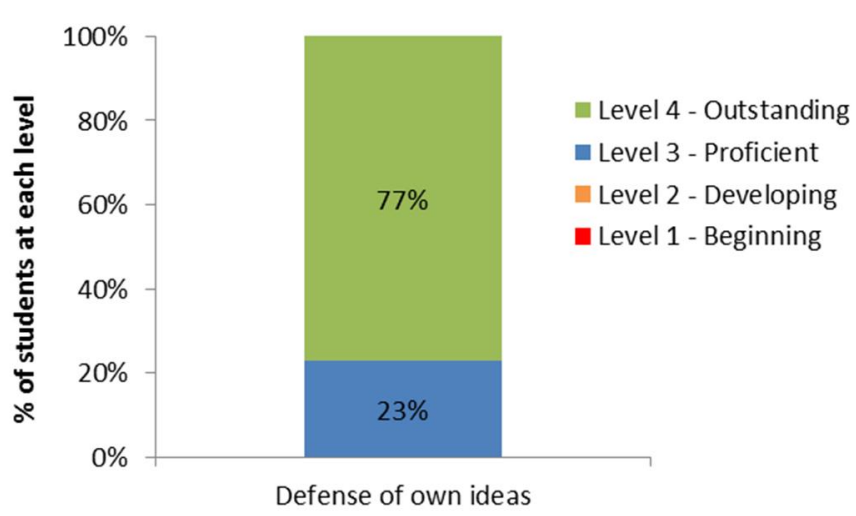


(e)

G-PI4 - English level - SABER PRO 2014

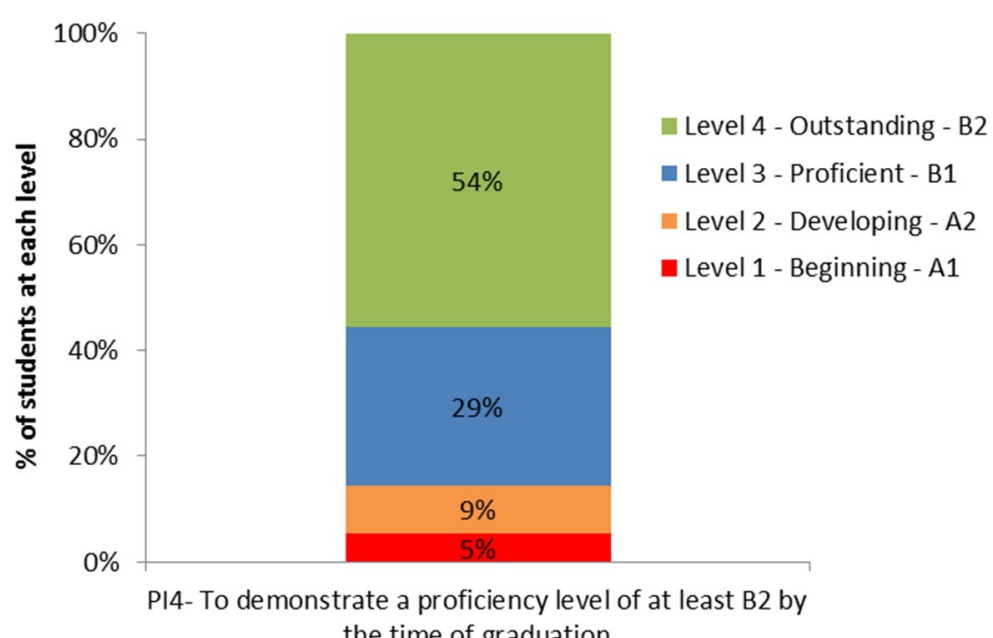

(f)

Outcome G - An ability to communicate effectively orally and written, both in Spanish

Figure 2 Assessment results for Outcome G

(e) Direct assessment results for G-PI4

(f) Complementary assessment results and English - Students outcome survey 2015-1

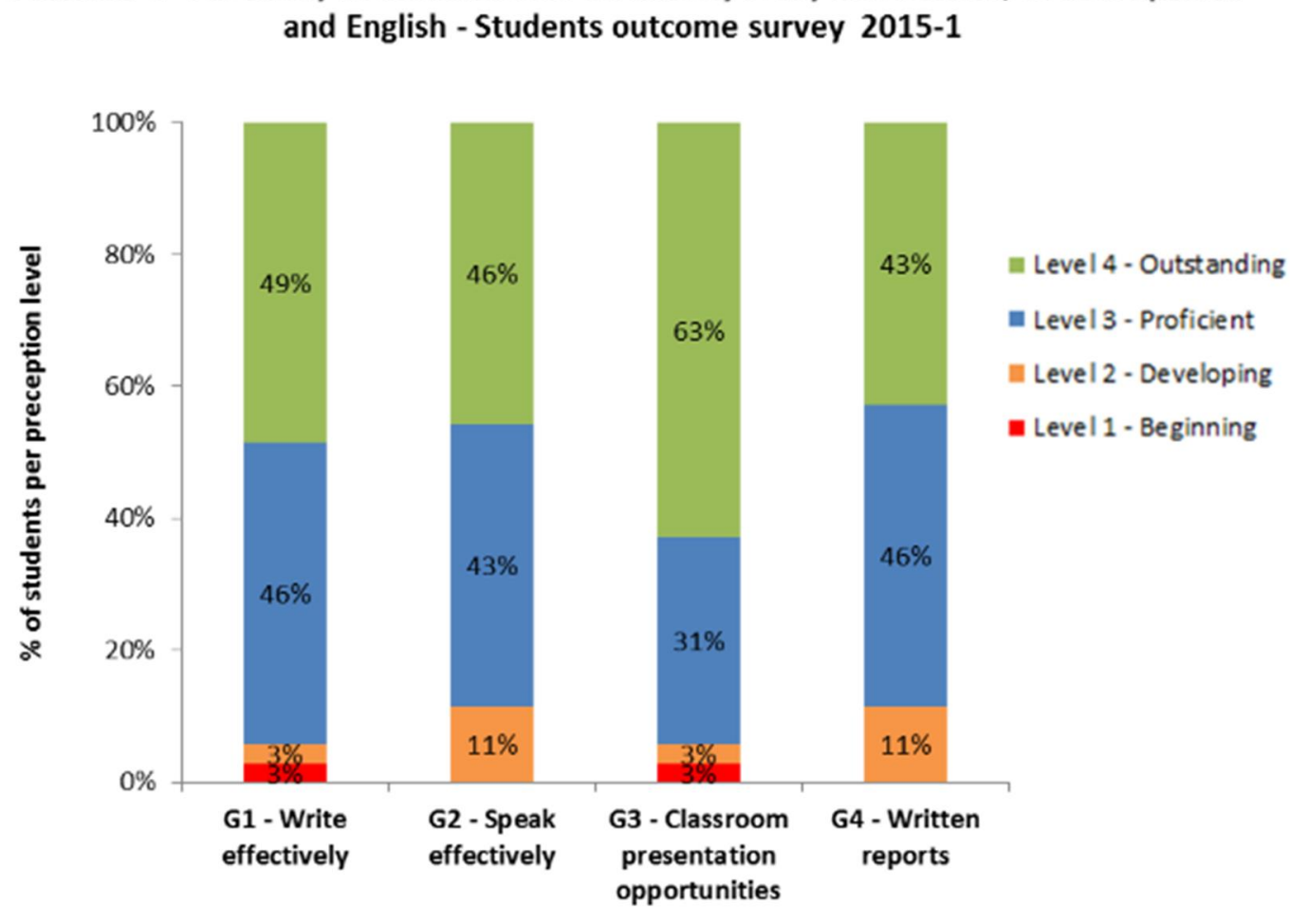




\begin{tabular}{|c|c|c|c|c|c|c|}
\hline $\begin{array}{l}\text { Performance } \\
\text { Indicator }\end{array}$ & $\begin{array}{c}\text { Source of } \\
\text { Assessmen } \\
\mathbf{t} \\
\end{array}$ & Methodology & $\begin{array}{l}\text { Popu- } \\
\text { lation }\end{array}$ & $\begin{array}{c}\text { Results: Observations and Possible } \\
\text { Causes }\end{array}$ & $\begin{array}{l}\text { Improvement } \\
\text { Actions }\end{array}$ & $\begin{array}{c}\text { Impl. Date } \\
\text { / Assigned } \\
\text { to } \\
\end{array}$ \\
\hline $\begin{array}{l}\text { G-PI1 - Produce } \\
\text { documents that } \\
\text { evidence } \\
\text { communication } \\
\text { strategy and } \\
\text { structure. } \\
\text { Documents must } \\
\text { feature correct } \\
\text { grammar and style }\end{array}$ & $\begin{array}{l}\text { Graduation } \\
\text { Project I (A) }\end{array}$ & $\begin{array}{l}\text { Students worked } \\
\text { on the } \\
\text { development of a } \\
\text { proposal that aims } \\
\text { to the solution of } \\
\text { an engineering } \\
\text { problem. }\end{array}$ & $\begin{array}{l}58 \text { st. }(23 \\
\text { teams) }\end{array}$ & $\begin{array}{l}\text { Observations: See Fig. } 1 \text { (a). PI-1 } \\
\text { (accomplished): For assessment purposes } \\
\text { PI-1 is decomposed in four aspects: } \\
\text { Vocabulary, ( } 77 \% \text { of the projects were at a } \\
\text { proficient level and } 17 \% \text { at an outstanding } \\
\text { level) Grammar ( } 57 \% \text { of the projects were } \\
\text { at an outstanding level, while } 33 \% \text { were at } \\
\text { a proficient level), Cohesion ( } 47 \% \text { of the } \\
\text { projects were at an outstanding level and } \\
40 \% \text { at an outstanding level) and } \\
\text { Coherence ( } 70 \% \text { of the projects were at an } \\
\text { outstanding level while } 27 \% \text { were at a } \\
\text { proficient level. Possible causes: (1) } \\
\text { Since it was accomplished it is recognized } \\
\text { the need of revising the threshold }\end{array}$ & $\begin{array}{l}\text { During the formative } \\
\text { process, the written } \\
\text { communication } \\
\text { aspects should be } \\
\text { emphasized. Courses } \\
\text { like Introduction to } \\
\text { Engineering, Writing } \\
\text { Workshop I and } \\
\text { Quality in Operations } \\
\text { could assess the } \\
\text { proposed written } \\
\text { components. }\end{array}$ & $\begin{array}{c}\text { 2015-2/ } \\
\text { Outcome } \\
\text { Leader and } \\
\text { Writing } \\
\text { center }\end{array}$ \\
\hline $\begin{array}{l}\text { G-PI2 -Produce } \\
\text { oral presentations } \\
\text { that evidence } \\
\text { communication } \\
\text { strategy. } \\
\text { Presentations must } \\
\text { feature appropriate } \\
\text { language, style, } \\
\text { flow and nonverbal } \\
\text { language (gestures, } \\
\text { eye contact, poise, } \\
\text { voice level and } \\
\text { tone). }\end{array}$ & $\begin{array}{l}\text { Graduation } \\
\text { Project II } \\
\text { (A) }\end{array}$ & $\begin{array}{l}\text { Students } \\
\text { developed their } \\
\text { proposed plan to } \\
\text { solve an } \\
\text { engineering } \\
\text { problem and } \\
\text { delivered a final } \\
\text { report. }\end{array}$ & $\begin{array}{l}37 \text { st. ( } 19 \\
\text { teams) }\end{array}$ & $\begin{array}{l}\text { Observations: See Fig. } 1 \text { (b). } \\
\text { PI-2 (accomplished): the aspects of } \\
\text { Introduction and Conclusion associated } \\
\text { with the oral presentation the students } \\
\text { meeting at outstanding and proficient level } \\
\text { are } 64 \% \text { and } 43 \% \text { respectively. Most } \\
\text { groups performed at a proficient level } \\
\text { above } 70 \% \text { for the main aspects of the } \\
\text { presentation. Possible causes: (1) Since it } \\
\text { was accomplished it is recognized the need } \\
\text { of revising the threshold }\end{array}$ & $\begin{array}{l}\text { During the formative } \\
\text { process, oral } \\
\text { communication } \\
\text { aspects should be } \\
\text { reinforced in courses } \\
\text { such as Writing } \\
\text { Workshop II and } \\
\text { Computer Assisted } \\
\text { Design could be } \\
\text { aligned }\end{array}$ & $\begin{array}{l}\text { 2015-2/ } \\
\text { Outcome } \\
\text { Leader }\end{array}$ \\
\hline
\end{tabular}




\begin{tabular}{|c|c|c|c|c|c|c|}
\hline \multirow{2}{*}{$\begin{array}{l}\text { G-PI3 - Build and } \\
\text { defend arguments } \\
\text { evidencing } \\
\text { coherence between } \\
\text { conclusions and } \\
\text { their supporting } \\
\text { premises. }\end{array}$} & $\begin{array}{l}\text { Graduation } \\
\text { Project II } \\
\text { (A) }\end{array}$ & $\begin{array}{l}\text { Students } \\
\text { developed their } \\
\text { proposed plan to } \\
\text { solve an } \\
\text { engineering } \\
\text { problem and } \\
\text { delivered a final } \\
\text { report. }\end{array}$ & $\begin{array}{l}37 \text { st. }(19 \\
\text { teams) }\end{array}$ & $\begin{array}{l}\text { Observations: See Fig. } 1 \text { (c). } \\
\text { PI-3 (not accomplished): } 50 \% \text { of the } \\
\text { students were in a proficient level. } \\
\text { Possible causes: (1) Students are not } \\
\text { exposed to class activities before } \\
\text { Graduation Project II that allow them to } \\
\text { build and defend an argument e.g debates. }\end{array}$ & \multirow{2}{*}{$\begin{array}{l}\text { The argumentation } \\
\text { aspect should be } \\
\text { taken into } \\
\text { consideration, and an } \\
\text { alignment with earlier } \\
\text { courses such as Logic } \\
\text { and Argumentation } \\
\text { should be revised }\end{array}$} & \multirow[t]{2}{*}{$\begin{array}{l}\text { 2015-2/ } \\
\text { Outcome } \\
\text { Leader }\end{array}$} \\
\hline & $\begin{array}{l}\text { Professional } \\
\text { Internship - } \\
\text { IND }\end{array}$ & Employer Survey & 48 st. & $\begin{array}{l}\text { Observations: See Fig. } 1 \text { (d). } \\
\text { PI-3 (accomplished): } 77 \% \text { of the students } \\
\text { perform at an outstanding level. Possible } \\
\text { causes: (1) Since it was accomplished it is } \\
\text { recognized the need of revising the } \\
\text { threshold }\end{array}$ & & \\
\hline $\begin{array}{l}\text { G-PI4 - } \\
\text { Demonstrate a } \\
\text { proficiency level of } \\
\text { at least B2 by the } \\
\text { time of graduation }\end{array}$ & $\begin{array}{l}\text { National } \\
\text { Standard } \\
\text { test Saber } \\
\text { PRO }\end{array}$ & $\begin{array}{l}\text { Use the National } \\
\text { Standard test } \\
\text { Saber PRO results }\end{array}$ & 112 st. & $\begin{array}{l}\text { Observations: See Fig. } 2 \text { (e). } \\
\text { PI-4 (accomplished): results show that is } \\
\text { meeting the expected level of attainment } \\
\text { with } 83 \% \text { of the students at the outstanding } \\
\text { and proficient levels. Possible causes: (1) } \\
\text { Since it was accomplished it is recognized } \\
\text { the need of revising the threshold }\end{array}$ & $\begin{array}{l}\text { In the long term, IE } \\
\text { students should be } \\
\text { exposed to } \\
\text { disciplinary texts in a } \\
\text { second language } \\
\text { (English). Each } \\
\text { semester, at least one } \\
\text { elective course in } \\
\text { English should be } \\
\text { offered }\end{array}$ & $\begin{array}{c}\text { IE } \\
\text { Department } \\
\text { Head }\end{array}$ \\
\hline $\begin{array}{l}\text { Complementary } \\
\text { Assessment } \\
\text { Sources }\end{array}$ & $\begin{array}{l}\text { Student } \\
\text { outcome } \\
\text { program } \\
\text { survey }\end{array}$ & $\begin{array}{l}\text { Questionnaire } \\
\text { applied to students }\end{array}$ & 35 st. & $\begin{array}{l}\text { See Fig. } 2 \text { (f). Accomplished: more than } \\
70 \% \text { of the graduating students are } \\
\text { satisfied with the strategies delivered by } \\
\text { the program to develop the ability to } \\
\text { communicate effectively (orally and } \\
\text { written), both in Spanish and English. }\end{array}$ & $\begin{array}{l}\text { Improvement actions } \\
\text { associated with all PI } \\
\text { will impact positively } \\
\text { the perception of the } \\
\text { students. }\end{array}$ & NA \\
\hline
\end{tabular}



This document was created with Win2PDF available at http://www.win2pdf.com. The unregistered version of Win2PDF is for evaluation or non-commercial use only. This page will not be added after purchasing Win2PDF. 